\title{
Intercropping of Corn With Some Selected Legumes for Improved Forage Production: A Review
}

\author{
M. D. Belel ${ }^{1,4}$, R. A. Halim ${ }^{1}$, M. Y. Rafii ${ }^{3} \&$ H. M. Saud ${ }^{2}$ \\ ${ }^{1}$ Department of crop science, Universiti Putra Malaysia, Malaysia \\ ${ }^{2}$ Department of Agricultural Technology, Universiti Putra Malaysia, Malaysia \\ ${ }^{3}$ Institute of Tropical Agriculture, Universiti Putra Malaysia, Malaysia \\ ${ }^{4}$ Department of Agricultural Technology, Federal Polytechnic, Mubi, Malaysia \\ Correspondence: M. D. Belel, Department of crop science, Universiti Putra Malaysia, Malaysia. Tel: \\ 60-166-748-283. E-mail: mustaphabelel@gmail.com
}

\author{
Received: December 5, 2013 Accepted: December 26, 2013 Online Published: February 15, 2014 \\ doi:10.5539/jas.v6n3p48 URL: http://dx.doi.org/10.5539/jas.v6n3p48
}

\begin{abstract}
Low forage quality and low corn yield experienced due to continuous monoculture resulting from persistent soil depletion in the developing world have generated the need for a sustainable practice to improve quality and yield of aforementioned. This review examines the salient issues that relates to the effect of intercropping some selected legume in different cropping patterns with corn in order to improve the yield and forage quality of corn, and that of quality feed/forage production. Two legumes species namely: Bambara groundnut and Peanut were the key crops focused with the main corn crop in this review work.
\end{abstract}

Keywords: intercropping, legumes, forage, quality, production, cereals

\section{Introduction}

Improving forage yield and quality has been in the Centre stage in the last few years in the livestock sub sector of agriculture. Achieving this noble target is viewed in many ways among which is intercropping of cereals with legumes. Intercropping, which is the simultaneous cultivation of crops is a predominant cropping system in developing countries; it is currently accomplished in many portions of the world (Francis, 1986). It is an advanced agro technic (Thayamini \& Brintha, 2010) of growing two or more crops at the same time during the same season in the same piece of land (Geiler et al., 1991). The system has been shown not only to be more efficient than sole cropping (Remison, 1978) but also to improve the overall ecology (Adelana, 1984). It is eminent to point out that to produce additional food from less expanse of land through more efficient use of natural means with minimal impact on the environment in order to meet the increasing population request (Amos et al., 2012). The main idea of intercropping is to get improved productivity per unit land area and time, and also impartial and judicious exploitation of land resources and farming inputs including labour. Most studies on intercropping focused on productive and sustainable system, ie on the legume-cereal intercropping (Fusuo \& Li, 2003). Legumes in maize based cropping systems are considered to be better alternatives for securing nitrogen economy and increasing yield of maize besides bonus yield, greater productivity per unit time and space and higher net returns of intercropping system over monoculture (Thayamini \& Brintha, 2010). Its effect on $\mathrm{N}$ input from symbiotic nitrogen fixation into the cropping system and reduction of negative impact on the environment are eminent (Jensen, 1996) Intercropping delivers a fast and good ground shield and also allows the roots to adventure soil nutrients at several depths (Steiner, 1991). The traditional cultivators seem to have unconsciously planned their cropping system with a view of maintaining the soil richness because intercropping produces a constant and workable agro ecosystem. Ijoyah and Fanen (2012) further reports that the choice of crop combination is key to successful intercropping. Incompatibility factors such as planting density, root system and nutrient competition need to be considered (Ijoyah \& Jimba, 2012). Farmers practice intercropping with a wide array of crops, consisting ordinarily of a major crop and other insignificant crops, however, it is pertinent that the selection of compatible crops be given priority as this depends on their growth habit, land, light, water and fertilizer utilization (Thayamini \& Brintha, 2010). Intercropping plays a vital role in subsistence food production in both advanced and emerging countries (Adeoye et al., 2005). Legumes can relocate fixed $\mathrm{N}$ to intercropped cereals through their joint 
growing period and this $\mathrm{N}$ is an imperative resource for the cereals (Bhagad et al., 2006). In a general note, Shafik and Soliman (1999) put it that intercropping may lead to overall yield advantage. In intercropping systems, all the environment resources utilized to maximize crop production per unit area per unit time. Several researches have been reported on intercropping (Mandal et al., 1990; Brintha \& Seran, 2009; Ijoyah, 2012). And mostly focusing on cereal-legume based (Ofori \& Stern, 1987; Hugar \& Palled, 2008) and proved successful.

\subsection{Corn}

Maize (Zea mays L) is an annual crop of great importance, it was domesticated from America. It is a cereal crop belonging to the Family Poaceae that is used as a source of carbohydrate to both human (in the developing countries) and animal feed worldwide due to its high feeding value (Undie et al., 2012) it is recently used in production of biofuel. It is equally well accepted for feed ingredient and can contribute up to $30 \%$ protein, $60 \%$ energy, and 90\% starch in animal diet (Dado, 1999). Maize is one of the important crops occupying third position next to wheat and rice in cereal production in the world. Maize has been recognized as a common component in most intercropping system. It seems to lead as the cereal constituent of intercrop and is regularly combined with dissimilar legumes (Maluleke et al., 2005). Maize yield is generally higher in high solar intensities, lower night temperatures and lower incidence of pest and diseases (Adesoji et al., 2013).

\subsection{Bambara Nut}

Bambara Groundnut (Vigna subterranean L verdc) is a crop belonging to the legume specie of the family fabaceae (Bamshaiye et al., 2012), and is regarded as the third most important crop after groundnuts and cowpeas in Africa (Alhassan et al., 2012). Bambara nut is an herbaceous, intermediate $(0.30-0.35 \mathrm{~m}$ in height), annual plant with creeping stems at ground level. The entire plant is similar to peanut, flat with compound leaves of three leaflets. The leaves with erect petiole are alternate and trifoliate. The peduncles are auxiliary, elongating from the stem nodes, each peduncle bearing one to three flowers. The flowers which are pale yellow are borne on the freely branching stem, which after fertilization grows down towards the soil, taking the developing seed in it (Jane et al., 2012). It forms pods and seeds on or just below the ground. It is seen as a snack or food supplement but not a lucrative cash crop (Bamshaiye et al., 2012). It is used for both human and animal consumption. (Bamshaiye et al., 2012). It is conventionally classified as a bean, but its seeds are actually dug from the ground like peanut. The crop is indigenous to Africa (Jane et al., 2012). Although occasionally grown in Asia, South America, Oceania and elsewhere, its cultivation is rare outside the African continent (Hillocks et al., 2012). The distribution of wild bambara groundnut is known to extend from Jos Plateau and Yola in Nigeria, to Garoua in Cameroon (Goli, 1997). The crop can produce high yield levels with estimated world annual production at 330,000 tonnes. It has several natural agronomic advantages including high nutritional value, drought resistance (Bamshaiye et al., 2012). It is resilient to high temperature and is fit for marginal soils where other leguminous crops cannot be developed (Alhassan et al., 2012), and does well on a deeply ploughed field with a fine seedbed or ridges (on water logged soils), allowing the plant to bury its developing fruit (Alhassan et al., 2012). It grows best in average annual rainfall of between $900-1000 \mathrm{~mm}$. it is also cultivated at altitude's ranging from 0-1550 meters (Wamba et al., 2012). The plant has latent to improve malnutrition and increase food accessibility. The seed which vary in shapes, sizes, and colour with some being round, or elliptical in shape and a cream, brown red mottled or black colours and weight ranging between 280 and $320 \mathrm{~g}$. the seed makes a complete food, as it contains sufficient amount of protein (19\%), carbohydrate $(63 \%)$, and fat $(6.5 \%)$ (Bamshaiye et al., 2012). It is richer than groundnut in essential amino acid such as isoleucine, leucine, methionine, phenylalanine, threonine, and valine (Alhassan et al., 2012). The harvest of this crop is achieved when the plant attain maturity by the entire foliage turning yellow and dries up. The duration of the crop life cycle is between 100-180 days Bambara groundnuts have for long been used as animal feed (Jane et al., 2012) and seeds have been successfully used to feed chicks (Alhassan et al., 2012). The leaves are suitable for animal grazing, because they are rich in nitrogen and phosphorus (Jakusko \& Belel, 2009; Bamshaiye et al., 2012). Livestock, especially goats are very fond of the stem or stalk, which they are allowed to graze on at the end of the season (Bamshaiye et al., 2012). Also the leaves can be pounded with those of lantana trifolia L., then water is added to create a solution used to rinse livestock as a defensive against ticks. This solution is used as a pesticide on vegetables (Bamshaiye et al., 2012). Also the flour could also be used as composite flour used for cereal based confectionaries e.g. Biscuit $\backslash$ Cakes, bread (Alhassan et al., 2012).The excerpt from the nut particularly the protein extracts can be used directly in cosmetic Inventions and offers specific and prominent effects. The nut can also be used rather freely to replace the high-prized lumps of meat without foregoing adequate nourishment (Bamshaiye et al., 2012). 


\subsection{Peanut}

Ground nut (Arachis hypogaea $\mathrm{L}$ ) is an important annual legume worldwide. Iit is the $13^{\text {th }}$ worldwide most important food crop, and fourth important oilseed crop (Smith, 2002) known for its oilseed, food and animal feeds (Mangasini et al., 2012) the crop is mostly involved in crop rotation in the sub Saharan Africa. Its world production stood at 28.5 million tons/annum. (ICRISAT, 2009). About $90 \%$ of the world's groundnut production happens in the tropical and semi-arid tropical areas (Hamidou et al., 2013), in countries including: China, India, Nigeria, Indonesia, Senegal, USA, Argentina, and South America (Mangasini et al., 2012). The crop requires about $500 \mathrm{~mm}$ to $1600 \mathrm{~mm}$ of annual rainfall on a well-drained light sandy loamy soil (Taru et al., 2008). Abundant of the world's groundnut production areas are characterized by high temperature and low or unpredictable rainfall even though it was reported that Groundnut is delicate to temperature (Vara Prasad et al., 1999). Plant reactions to high temperature differ with plant type and phenological periods (Wahid et al., 2007). Reproductive developments are evidently affected by high temperatures in utmost plants, which lead to concentrated crop yield (Hamidou et al., 2013). The crop bears so many local names including Peanut, Earthnuts, Monkey-nuts, Goober. High quality easily digestible protein (25\%), edible oil $(50 \%)$, and carbohydrates (20\%) are contained in the seed (Sorrensen et al., 2004; Musa et al., 2012)

\subsection{Intercropping System}

The practice of cultivating two or more crops in the same space and at the same time is common among smallholder farmers (Seran \& Brintha, 2010), this common combination in intercropping systems mostly involves cereal legumes (Ijoyah, 2012), particularly Maize - soybean, maize - cowpea, maize - groundnuts, milletgroundnuts, and rice - pulses (Matusso et al., 2012). Series of research work have been reported by scientist on cereal- legume intercropping (Waddington et al., 2007; Egbe, 2010; Osman et al., 2011; Ijoyah, 2012), with intercropping successes as compared to monocrop. With this, farmers can produce to exploit location specific agro-climatic circumstances for improved production (Bhagat et al., 2006). Intercropping systems is known to make a more efficient use of growth factors as they capture and make a better use of radiant energy (Matusso et al., 2012), available water and nutrients (Sullivan, 2003). Prevent pest and diseases, suppress weeds and maintain and improve soil fertility (Sanginga \& Woomer, 2009, Seran \& brintha, 2010). Cropping system refers to the spatial and temporal arrangement of different crops to exploit natural resources and enhance productivity per unit area and time (Gurigbal, 2010). The spatial arrangement of crops helps in the effective utilization of land, soil moisture, nutrients and solar radiation. This is brought about by choosing appropriate crops of varying morpho-physiological nature and planning their planting geometry to reduce mutual competition for resources and enhance complementarities to increase overall productivity. In general, this is achieved by intercropping systems (Gurigbal, 2010).

\subsection{Benefits of Intercropping}

The low input and high risk environment of the smallholder farmer benefits enormously from intercropping (Rana \& Pal, 1999). Cereal and legumes which has become a popular combination among farmers was probably due to legumes ability to combat erosion and raise soil fertility levels (Matusso et al., 2012). Flexibility, maximization of profit , minimization of risk, soil conservation and soil fertility improvement are some of the principal reasons for smallholder farmers to intercrop their farms/crops(Matusso et al., 2012). Further to that, they have the potentials to give higher yield than sole crops, greater yield stability and efficient use of nutrients (Seran \& Brintha, 2010). Similarly, better weeds control, improvement of quality by variety while cereal crops require larger area to produce same yield as cereals in an intercrop system (Ijoyah, 2012).

\subsection{Problems of Intercropping}

Reduction in yield of component crop may occur due to intense competition (Thole, 2007). The situation in which two or more plants share the same growth factors each far below their combined demands and in the same environment is known as competition (Thole, 2007). The basic morpho-physiological changes and agronomic features such as fertilizer application, sowing time, and proportion of crop mixture are basic determinants of competition between component crops. Where constituent crops are arranged in certain rows, the degree of competition is determined by the comparative growth rates, growth duration and proximity of roots of the diverse crops. The cereal component in a cereal-legume intercrop has advanced growth rate, height advantage, and a more widespread rooting system which gives it upper hand in competition with associated legumes. Ofori and Stern (1987) reported that the yield of the legume component decline on normal by about $52 \%$ of the sole crop yield whereas the cereal yield was condensed by only $11 \%$. Significantly, it was noted that the cereal constituent depresses the legume in an intercrop. This was attributed to abridged photosynthetic active radiation of the legume by the screening from cereal crop. 


\subsection{Effect of Intercropping on Growth and Yield of Maize}

Maize has been recognized as a common component in most intercropping system in the tropics (Ijoyah, 2012). Fawusi and wanki (1982) reported a high leaf area index and light interception for maize in mixture over sole crops. While Prasad and brooks (2005) found an increase in maize plant density to significantly affect the LAI in maize soybean intercropping. Thus, increase in the growth of maize was reported by Adesoji et al. (2013) to be as result nitrogen effects that lead to increase cell division, cell expansion and increase in size of all its morphological parts. Also Reddy and Reddi (2007) observed separately the grain yield of maize to have increased after intercropping with groundnut and green gram. The purpose of maximum maize-legume association is to reach a full yield of the maize plus selected legume yield (Chui \& Richards, 1984). But however, reported decline in yield of maize as a result of varying spacing in intercrop with cowpea. This further agrees with the report of Gangwar and Sharma, (1994) that there was decreased yield of maize due to intercropping of legumes namely cowpea, clusterbean, sunhemp and dhiancha. Also experiment conducted at the Indian Agric. Research Institute revealed a significant dry matter accumulation of maize and groundnut intercropped in the 1:1 row ratio arrangement (Aravind kumar, 2004). Similarly, Maluleke et al. (2005) found maize dry matter was reduced with increasing Lablab population. Mangasini et al. (2012) found the vegetative growth of component crop in a mixture is affected by intercropping. Thayamini and Brintha (2010) noted that the planting pattern of the maize and legume did not affect the yield of maize. Chui and Richards (1984) reports that intercropping hindered maize tasseling and silking by up to 2 days, particularly at the full population concentration of soybeans. Intercropping maize with cowpea was seen to significantly decrease ear length, cob length, dry cob weight, dry grain yield and dry total plant biomass (Egbe et al., 2010). Ali and Mohammad (2012) observed that the highest dry leaf/dry stem yield and total protein of plant was related to forage corn intercropping with Karaj and Multicut respectively. Yield increased that was noticed in a maize/soybean strip intercropping arrangement were primarily due to the upsurge in the boarder rows of maize together to soybeans ( $\mathrm{Li}$ et al., 2001) Plant density affects both intra- and interspecific competition and has particularly a strong effect on grain yield of maize (Flores-sanchez et al., 2013). Maize - legume intercrop could substantially increase the quality and quantity of forage (Ali \& Mohammad, 2012). Farmers' field was however noticed to have had the highest amount of vegetative biomass when legume crops are intercropped with maize (Amos et al., 2012).

\subsection{Effect of Intercropping on Growth and Yield of Legumes}

Several research works have been reported on the response of legumes to intercropping predominantly with annual cereal crops. Bhagad et al. (2006) reported that Intercropping arrangement did not influence 100 - kernel mass of groundnut, however, number of pods per hill, weight of pods apiece hill and per cent shelling were significantly subjective due to different treatments. Research work also revealed that space for higher cereals can be altered to a certain degree without reducing its yield while providing a more promising environment for the intercropped legume (Chui \& Richards, 1984). Hongchun et al. (2013) reported that intercropping with maize did not disturb fresh weight of peanut associated with monocropping. The use of twin rather than single irregular rows of each species improved intercrop soybean yield without materially varying maize performance comparative to mono cropping (Maluleke et al., 2005). Intercropping significantly condensed the number of soybeans leaves per plant by $58 \%$, leaf area index (LAI) by $75 \%$ and phytomass at start seed - filling by $78 \%$ (Maluleke et al., 2005), however, Chui and Richards (1984) maintained that grouping maize plants at three to a hill enlarged intercrop soybean leaves per plant, LAI and phytomass relative to the conservative maize planting of one plant per hill. Soybeans yield was concentrated by up to $90 \%$ in intercropping with maize in the equal row (Dalal, 1977). Legumes are viewed as serious component in conservation Agriculture (Meyer, 2010).

\subsection{Effect of Intercropping on Nutrients Uptake}

When peanut and maize raise together, phytosiderphore released from maize roots may mobilize $\mathrm{Fe}$ (III) and profit the iron nutrition of peanut plant (Fusuo \& Li, 2003). Peanut/maize intercropping is known to progress Fe nutrition in all peanut tissues (Hongchun et al., 2013). Enhancement in the Fe nutrition of peanut intercropped with maize was mainly caused by rhizosphere collaboration between peanut and maize (Zuo et al., 2000). Thus, Hongchun et al. (2013) further states that in peanut/maize intercropping, the secretion of phytosiderophores from maize in the intercrop arrangement may contribute to the improvement of Fe nutrition of the peanut. Even when Geiler (2001) reported soil $\mathrm{pH}$ to have extensively influence nodulation and can make deficiency of some essential nutrients such as $\mathrm{P}$ and Mo, it was further reported that intercropping greatly augments $\mathrm{Fe}$ and $\mathrm{Zn}$ concentration in seeds of peanut (Hongchun et al., 2013). Li et al. (2001) reported that nitrogen acceptance by maize in an intercrop is greater as relate to sole cropping. The greater $\mathrm{N}$ acquisition by a non - legume crop intercropped with a legume is often reported in literature (Francis, 1986; Vandermeer, 1989; Stern, 1993). This may probably be due to the effect of competition. However, nitrogen attainment by soybeans was not significantly affected by intercropping. 
Similarly, phosphorus achievement by soybean was significantly amplified by $\mathrm{P}$ application under intercropping and by intercropping below $\mathrm{P}$ application ( $\mathrm{Li}$ et al., 2001). Legumes as a catch crop can reduce nitrate and $\mathrm{K}$ leaching (Askegaard \& Eriksen, 2008), and act not only as a N2 fixing crop but also as a catch crop by taking up additional soil minerals N,P, and K . (Flores-sanchez et al., 2013). These findings make legumes an important tool in the cropping systems where $\mathrm{N}$ and $\mathrm{K}$ are the major yield limiting factors (Flores-Sanchez et al., 2011, 2012a). Rusinamhodzi et al. (2012) reports that deficiencies of micro nutrients such as Zinc, molybdenum and boron in the field may bound legume growth as well as limit nitrogen fixation. At Main Agricultural Research Station, Dharwad, Karnataka, uptake of nitrogen, phosphorus, potassium by maize was found to reduced significantly due to intercropping $\left(263,13\right.$ and $\left.138 \mathrm{NPK} \mathrm{kg} \mathrm{ha}^{-1}\right)$ as against sole cropping $(305,16$ and $188 \mathrm{NPK}$ $\left.\mathrm{kg} \mathrm{ha}^{-1}\right)$. Uptake of nitrogen with greengram $\left(284 \mathrm{~kg} \mathrm{ha}^{-1}\right.$ was significantly developed than with cowpea (239 kg $\left.\mathrm{ha}^{-1}\right)$ and soybean $\left(247 \mathrm{~kg} \mathrm{ha}^{-1}-1\right)$ as intercrops, the nitrogen uptake was maximum in 1:1 row ratio $\left(274 \mathrm{~kg} \mathrm{ha}^{-1}\right)$ compared to 1:2 row ratio $\left(251 \mathrm{~kg} \mathrm{ha}^{-1}\right)$ (Kanakeri, 1991). Further, among different intercrops, cowpea noted maximum uptake of nitrogen $\left(68 \mathrm{~kg} \mathrm{ha}^{-1}\right)$, phosphorus $\left(2 \mathrm{~kg} \mathrm{ha}^{-1}\right)$ and potassium $\left(18 \mathrm{~kg} \mathrm{ha}^{-1}\right)$ followed by soybean with 60,2 and $18 \mathrm{~kg} \mathrm{ha}^{-1} \mathrm{NPK}$, separately.

\subsection{Intercrop Productivity}

Intercrop productivity, otherwise called yield advantage is core in any intercrop studies. Production systems involving inter planted food crops are widespread in tropical latitudes (Thayamini \& Brintha, 2010). Intercrops are greatest productive when the component crop varies greatly in growth duration so that their maximum condition for growth resources occurs at different periods (Ijoyah, 2012). The interaction of several factors will optimize the most effective use of restrictive resources in intercrop (Fukai \& Trenbath, 1993). These factors range from the genetic constitution of the component crops to environmental and agronomic manipulation of the microenvironment (Fukai \& Trenbath, 1993). High intercrop productivity is attained if early maturing constituent is grown with little interference from the late growing crop. Thus, the choice of accurate cultivars and agronomic manipulations to certify the most effective use of limiting resources is key part for high crop yield (Thayamini \& Brintha, 2010). The biggest yield advantage and complementary effect occur when component crops have different growing periods to make their demand on resources at different times (Ijoyah, 2012). Fukai (1993) maintained that legumes are a shared component of an intercrop, and their skill to fix nitrogen often supports the productivity of the intercrop, or subsequent crops. In comparison to sole cropping yield benefit have been recorded in many intercropping system, including: maize/bean, sorghum/soybean, maize/cowpea, wheat/mungbeans, wheat/chickpea, maize/fababeans etc (Li et al., 2001). Most published intercropping mixture with significant yield advantage were from legume/non legume combination (Li et al., 2001).

\subsubsection{Land Equivalent Ratio (LER)}

This is the relative area of land under monocrop which is needed to obtain the yield produced in intercropping (Wiley, 1979). Rao and Willey (1980) showed a clear variation in duration of maturity of component crop was due to largely the advantage in yield, which clearly allowed in this combination for a good resource use with time. Khan et al. (1992) in an experiment involving maize and soybean recorded a high LER of 1.40 as a result of sowing them in same rows, while a low LER of 0.95 involving the same crops was noted but on alternate rows. In Brazil, Raposa et al. (1995) recorded high LER in intercrop involving 2:2 row arrangements than with monocrop. Yield advantages in maize based intercropping were also reported in Ethiopia (Fininsa, 1997) that LER for intercrop was far above that of monocrop with maximal relative yield advantage of $28 \%$. Similarly, altered maize $(75 \mathrm{~cm})$, rice bean $(30 \mathrm{~cm})$ row proportions recorded yield advantage in terms of land use, and for moisture. LER values in 1:2 row ratio at 100 per cent + zero per cent fertilizer (maize $60 / 90 \mathrm{~cm}$-rice bean $30 \mathrm{~cm}$ ), in 2:3 at 100 per cent fertilizer (maize $150 / 15$-rice bean $30 \mathrm{~cm}$ ) and in 2:5 at 100 per cent +100 per cent fertilizer were 1.84, 1.87 and 1.97 respectively (Lakra et al., 2000).

\subsubsection{Area Time Equivalent Ratio (ATER)}

The LER method was modified by Hiebsch and Macollam (1980) to include the duration of the crop present on the land from planting to harvest. This method is known as the area time equivalent ratio (ATER). In maize + cowpea/soybean intercropping system, the yield advantages ranged from 22 to 32 per cent based on LER method 19 to 25 per cent based on ATER method over sole crops and thus LER productivity estimates were greater than that of ATER (Allen \& Obura, 1983). The higher ATER (1.38) was recorded in the maize (3 plants $\mathrm{m}^{-2}$ Phaseolus vulgaris in 1:2 row ratio than Phaseolus vulgaris and maize grown as sole crops (Gardner \& Kisakye, 1990). At Pantnagar, in maize based intercropping systems, Halikatti and Banarasilal (1998) recorded higher ATER value (1.18) with one row of blackgram followed by two rows of blackgram between maize pairs compared to other cropping systems. Similarly, Pandita et al. (2000), also reported that maize and Phaseolus 
vulgaris at 1:2 row ratio gave the maximum ATER (1.48) with highest maize equivalent yield (78.8 $\left.\mathrm{q} \mathrm{ha}^{-1}\right)$. At Dharwad, in maize based intercropping systems, Mohan (2003) recorded higher ATER value (1.65) with two rows of rice bean between maize spaced at $90 \mathrm{~cm}$ followed by two rows of soybean (1.63) and frenchbean (1.51) compared to other cropping systems.

\subsection{Effects of Bambara Nut Intercrop on Growth and Yield of Maize}

Bambara's ground nut potential of contributing to food security has fuelled an increasing research interest (Jane et al., 2012). Karikari (2001) reported that intercropping maize with Bambara nut did not affect the number of cobs and weight of seed in maize. Similarly it was also reported that yield did not reduce nor increase in the intercrop of sorghum and Bambara nuts (Gabatshele et al., 2012). On the contrary, Ogah and Ogbodo (2012) reported a significant increase in total grain yield of maize when intercropped with Bambara nut than in the sole crop maize. The total percentage yield loss due to stem borer infestation in maize was also reported to be significantly lower in intercrop with Bambara nut. He further maintain that the 2:2 maize/Bambara nut intercrop produced meaningfully higher number of cobs, quantity of seeds, and seed weight with less infestation than 1:1 maize/Bambara intercrop (Ogah and Ogbodo 2012). Maize plants that were grown in intercrop with Bambara nut were also found to have a significant reduction in the density of larvae, number of borers and percentage dead heart (Ogah \& Ogbodo, 2012).

\subsection{Effects of Groundnuts on Growth and Yield of Corn}

Groundnut is very commonly intercropped with maize in Southeast Asia and Africa. It was reported from west Cameroons that groundnuts a major crop are grown with maize at a fairly low density with impressing high yield per pure stand (Reddy \& Reddi, 2007). Another study, revealed a very rapid growth rate of millet in intercrop, with ground nuts achieving $8134 \mathrm{~kg} / \mathrm{ha}$ of dry matter in 85 days. Sole groundnut growth rate however was slower, and achieved $4938 \mathrm{~kg} / \mathrm{ha}$ of dry matter in 105 days. Also observed in another study of Groundnuts/Maize intercropping was the mean yield of groundnut was significantly higher when sown four (4) weeks earlier than maize. Generally, several reports revealed that on the maize/groundnut combination is that $\mathrm{g} / \mathrm{nut}$ yield is readily depressed by competition from Maize (Thayamini \& Brintha, 2010). Conversely, ICRISAT reported a poor maize growth in Maize/Groundnut intercrop that was without $\mathrm{N}$-fertilizer application, and there was no visual evidence of growth being any better if the groundnuts intercrop were present. However, where nitrogen was applied to the maize, the growth was suppressed (Thayamini \& Brintha, 2010), and the residual benefits rapidly diminished (Rao \& Willey, 1980). Bhagad et al. (2006) further emphasized that the yield Mechanisms of maize like length of cob and regular weight of cob were meaningfully higher once groundnut + sweet corn were intercropped in 3:1 ratio and provided with $125 \%$ RDF. Also Koli (1975) reported a little productivity of maize-groundnut mixture which he say was possibly due to relatively high maize population such that the nearness of maize to groundnut did not make for considerable spatial complementary among the two crops.

\subsection{Effect of Legumes Intercrop and Cropping System on Soil Fertility}

Soil fertility problems are not only an agronomic issue, but also strongly related to economic and social issues. Intercropping tend to ameliorate some of the fertility constraint of poor farmlands. Adeleke and Haruna (2012) mentioned that pulses are usually intercropped with cereals and advance land productivity over soil amelioration. In a study, Vesterager et al. (2008) found maize and cowpea intercropping as beneficial on nitrogen poor soil. Maize /cowpea intercropping increases the amount of nitrogen, phosphorus, and potassium contents associated to monocrop of maize (Dahmardeh et al., 2010). Degraded and infertile soils are realized as a result of continuous monocropping and insufficient organic matter reprocessing coupled with occurrence of rainfall variability marked by common dry spells account for low crop yield (Amos et al., 2012). It was further noted that the understanding of the fact that maintenance and improvement of soil fertility cannot be exclusively through the use of predictable fertilizers (Amos et al., 2012). As a trait in legumes as cover crops, conservation involves minimum soil disturbance, permanent sol cover with living or dead plant resources, and diversified crop rotation and associated by legumes crops (Amos et al., 2012). Adeleke and Haruna (2012) also in the result of their findings revealed increase in total nitrogen after cropping any of the four legumes (soybean, cowpea, lablab and groundnut) and when the land was left fallow. This monumental increase in the total nitrogen was probably due to the ability of the legumes to fix atmospheric nitrogen in the soil through symbiotic $\mathrm{N}$ fixation. This symbiosis alone accounts for more than $20 \%$ of global biological nitrogen fixation and has been calculated to contribute 45-50 million tons of fixed $\mathrm{N}$ to agriculture each year (Geiler, 2001). Also the higher Cat ion Exchange Capacity (CEC) which plots that were previously cropped to legumes and had compared with the previous maize plot and fallow plots could be attributed to the leaf litter droppings which more or less serve as mulch and later decomposed to add nutrients to the soil (Adeleke \& Haruna, 2012). 


\subsection{Resource Use}

Intercropping systems can allow for spatial and temporal increase in nutrients uptake (Flores-sanchez et al., 2013). Spatial nutrients uptake can be increased through the increasing root mass (Undie et al., 2012), while temporal advantage in nutrients uptake occur when crops in an intercropping system have their peak nutrients demands at different times (Anders et al., 1996). Similarly, plants species with differing root and uptake patterns, like the case of legumes/cereals in intercrop, more efficient use of available nutrients may occur (Matusso et al., 2012), and higher uptake of nitrogen in the intercrop have been reported (Seran \& Brintha, 2010; Undie et al., 2012; Flores-sanchez et al., 2013) whereas in intercrop their similar root orientation tends to compete together at the same surface level (Hamidou et al., 2013). Intercropping amid high and low canopy crops is a mutual practice in tropical agriculture. Total system light Interception is resolute by crop geometry and foliage architecture (Trenbath, 1986). In intercropping between high and low cover crops is to improve light interception and hence yields of the smaller crops requires that they be planted among sufficiently wider rows of the taller ones (Seran \& Brintha, 2010). A favorable microclimate is created by intercropping for the lower plants growth (Azam-Ali et al., 1990). Keating and Carberry (1993) have reported a better use of solar radiation by intercropping soybeans and Maize. Further to that, intercropping enhanced the efficient use of strong light by maize and weak light by groundnuts which subsequently lead to yield advantage (Jiao et al., 2008). A combined leaf canopy might make better special use of light (Waddington and Edward, 1989). Growth of plants in any cropping system is vital and is determined by the availability of water and it efficient use lead to increase use of other resources (Dahmardeh et al., 2010). Water capture by intercrops is $7 \%$ higher than as compared to mono crop (Morris \& Garrity, 1993). Chui and Richards (1984) further maintained that during competition light obviously increase internode elongation on soybeans. Further to that, a delay in sowing of four weeks was long enough to avoid interspecific competition for light and nutrients and allow a good establishment of both maize and roselle (Flores-sanchez et al., 2013). Despite the beneficial effects of the intercropping to the cereal crops, it may also quicken soil nutrient depletion, particularly for phosphorous, due to added efficient use of soil nutrients and higher exclusion through the harvested crops (Mucheru-Muna et al., 2010). However, Chalka and Nepalia (2006) found that maize intercropped with soybean produced significantly lower NPK depletion and higher N uptake. And, recent efforts on replenishment of soil fertility in Africa have been through the introduction of legumes as intercrop and/or in rotation to minimize external inputs (Sanginga \& Woomer, 2009).

\subsection{Above and Below Ground Interaction in Intercrop}

Light is a vital factor that determines yield (Jeyakumaran \& Seran, 2007) especially when two morphologically dissimilar crops with different periods of maturity are intercropped (Ijoyah, 2012). Most of the advantages gotten from growing crops in intercrops come largely from the ways in which the crop mixtures balance each other in their exploitation of the environment (Oyewole, 2010). Indeed corn canopy architecture plays a significant role in the amount of sunlight radiation intercepted by other crops sown in an intercropping pattern (Metwally et al., 2012). The reduction of light intensity caused by the corn plant reduces the photosynthetic capacity of a second crop in an intercrop pattern (Metwally et al., 2012). Crop biomass buildup depends on light interception by leaves and on the effectiveness, with which the intercepted light is used to produce dry matter (Oyewole, 2010). Yield is determined principally by crop biomass, which in turn is determined by the quantity of radiation intercepted by the crop canopy (Oyewole, 2010). Any influence on the plant canopy either as a result of plant shading, which may result from intercropping, or other resources will affect yield. Crops - weeds competition is well - known by growth habit of crops (Dimitrios et al., 2010). Increased leaf cover in intercropping system helps to reduce weeds population once the crops are established (Beets, 1990). Flores-Sanchez et al. (2013) reported the contribution of above ground and below ground interaction of maize/wheat to be 50 and $59 \%$ respectively due to increase in nitrogen uptake. In a report by Hongchun et al. (2013), that through inter-specific root connections, peanut/maize intercropping contribute to the peanut nourishment of some nutrients elements including improvement in shoot zinc $(\mathrm{Zn})$, Phosphorus $(\mathrm{P})$, and Potassium $(\mathrm{K})$ concentration. The nitrogen $(\mathrm{N})$ productivity in both peanut and maize are improved. Mixed grown cereal and legumes have many advantages in terms of growth and some other agronomical properties (Singh et al., 1986; Putnam et al., 1986). There are also significant handicaps of mixed grown component crops such as root competition for water and nutrients and competition for light (Ofori \& Stern, 1987; Portes, 1984). Innis (1997) explained that water loss in the soil is reduced by various root systems, these increases transpiration and tend to produce a microclimate cooler than the surrounding. Flores-sanchez et al. (2013) further reported that the aboveground biomass of maize was not affected by legume intercrop neither in the maize monoculture nor in the maize-roselle mixture. It is clear that intercropping patterns caused a significant reduction in light interception through adjacent corn plants and produced taller component crop (Metwally et al., 2012). Legume residues generally create a mulching layer that increases the physical barrier for 
early germination; such effects do require sufficient residual organic material on the soil surface (Flores-Sanchez et al., 2013). In the soil, facilitative root interaction are most likely to be of great importance in nutrient-poor soil and low input agro ecosystem due to the crisis in inter specific competition or facilitation for plants growth factors (Dahmardeh, 2013). Maize benefit from intercropping with peanut due to extensive root system of maize for absorption of water and nutrients, and possibly that peanut via $\mathrm{N}$ fixation could secret $\mathrm{H}^{+}$in soil (Flores-Sanchez et al., 2013); this acidification of the rhizosphere could improve the dissolution of phosphorus in the high pH soil (Dahmardeh, 2013). Previous works reported that multiplicative processes in groundnut are sensitive to temperature. Increasing air and soil temperatures condensed fruit-set, number of pods and yield in groundnut (Hamidou et al., 2013). In addition, Oyewole (2010) showed that pod yield of groundnut genotypes declined by more than $50 \%$ when flowering and pod formation happened when maximum temperatures averaged $40{ }^{\circ} \mathrm{C}$. Nitrogen and phosphorus connections at the root zone of Bambara groundnut in the soil was reported to be the most probable reason for increases experiential in its growth and yield characters (Nweke \& Emeh, 2013).

\subsection{Forage Yield and Quality}

Maize - legume intercrop could considerably increase forage quantity and quality and lessening condition for protein supplement (Ali \& Mohammad, 2012). An important measure in grass land resource is the yield of forage; this defines the volume of dry matter obtainable to livestock (Shi et al., 2013). Thus, Legume - cereal configuration is considered as a management approach in producing both quality and quantity forage (Hamdollah, 2012). Intercropping cereals and legumes is important due to some potential benefits including the enhancement of forage quality through the complimentary outcome of two or more crops grown instantaneously on the same part of land (Hamdollah, 2012). As forage quality increases crude fiber also increase, while crude protein and ether extract of grasses declines, hence a negative association exist between forage quality and above ground biomass (Shi et al., 2013). Legume cultivars were reported to give a significant effect on plants heights, leaf fresh yield, stem fresh yield, total fresh yield, leaf dry yield, and entire proteins in plants (Ali \& Mohammad, 2012). It was also found that intercropping of maize with pulses meaningfully affected dry matter yield $\left(\operatorname{tha}^{-1}\right)$. Crude protein (CP) yield also was pointedly affected by intercropping systems as the highest CP yield was for the intercropping maize with Mungbeans (Hamdollah, 2012). Different ecological and social factors effects maize forage yield and quality (Emine et al., 2010). Shi et al. (2013) also found that environmental features such as temperature and soil fertility to disturb physiological developments, and so impact forage quality. High forage harvest means more crude fiber but fewer ether extract and crude proteins. It is the measure of dry matter made available to be consumed by Livestock (Shi et al., 2013). Many scholars reported that plant mass affects completely forage yield and maximum of its quality mechanisms (Jiwang et al., 2004; Emine et al., 2010). Corn is a high yield, high-energy forage crop (Jorge \& Joseph, 1999). It was maintained that the characteristic of good fodder corn is high forage yield, high digestibility (Emine et al., 2010). The lost in the food value of the forage (Leaves and stalk) in corn is rewarded by the grain making high quality forage need remained informed as an important facet of forage crop production (Hamdollah, 2012). Corn forage has low attentiveness of protein as related to legume forage (Jorge \& Joseph, 1999). Although cereals are extensive used in livestock nutrition, for their high dry material production and low price (Ghanbari-Bonjar, 2000), they have low sustenance value due to their low forage worth (Hamdollah, 2012). The total vitality value of corn forage does not vary much, it offers about $72 \%$ total digestible nutrients (TDN) whether it is browsed while green and emergent, or at prime of life (Troy, 2011). Forage quality of legume is high but has low dry matter making (Ross et al., 2005). The NDF and ADF contents are important in rations formulation because they reflect the amount of forage that can be used up by animals (Lithourgidis et al., 2006).

Protein content in forage may likely to decrease as dry matter yield increased (Foster \& Malhi, 2013), the protein content in forage tended to be superior for the cereals with the early planting date and lowest existences to harvest. Acid Detergent Fiber (ADF) content of forage retorted inversely to protein content of forage, but has a tendency to increase as dry matter yield increased with increased days to harvest (Foster \& Malhi, 2013). Widdicombe and Thelen (2002) reported that crude protein contents of forage maize were negatively related with plant density. Also, it was described that maize ear fraction and plant density had an undesirable relationship (Emine et al., 2010). Yilmaz et al. (2007) also reported that ear percentage decreased with cumulative plant density. Further to that, crude protein satisfied of forage corn decreased with increased plants density (Emine et al., 2010), while on the contrary, Jiwang et al. (2004) maintained that Acid detergent fiber (ADF) and CP contents increased with increased plants bulk. Hamdollah (2012) further reports that the CP yield and dry matter of formed forages increased by intercropping as associated with the maize monoculture. Also a significant reduction in NDF and ADF content was noticed during the legume /maize intercrop. This resulted in increased feed digestibility (Hamdollah, 2012). 


\section{Conclusion}

The relevance of improved forage production for our growing livestock industry is a key factor in the modern day crop production system. Intercropping which demonstrated a high technical potentials of crop - to - crop interaction for the better and higher quality food production, is in the lead in improving and ensuring the quality and quantity of food, for man, feed for animals, quality raw materials for the growing industries as well as a good environmental sustainability (such as improved fertility of soils, reduced prevalence of crop diseases in the field). In this review, critical areas of intercropping as they affect production especially in some legumes intercropped with maize were highlighted, and the advantages or otherwise were discussed. It is therefore imperative to adventure further into more studies to discover or rediscover the treasures of intercropping of different crops for the betterment of our life.

\section{References}

Adelana, B. O. (1984). Evaluation of maize-tomato mixed-cropping in south-western Nigeria. Indian J. Agric. Sci., 24(7), 564-569.

Adeleke, M. A., \& Haruna, I. M. (2012). Residual nitrogen contribution from grain legume to the growth and development of succeeding Maize crop.

Adeoye, G. O., Sridhar, M. K. C., Adeoluwa, O. O., \& Akinsoji, N. A. (2005). Evaluation of naturally decomposed solid waste from municipal dump sites for their manorial value in southwest Nigeria. Journal of Sustainable Agriculture, 26(4) 143-152. http://dx.doi.org/10.1300/J064v26n04_09

Adesoji, A. G., Abubakar, I. U., Tanimu, B., \& Labe, D. A. (2013). Influence of Incorporated short duration legume fallow and nitrogen on maize (Zea mays $L$.) growth and development in northern guinea savannah of Nigeria.American-EuroasianJ. Agric. And Env. Sci., 13(1), 58-67.

Alhassan, G. A., Kalu, B. A., \& Egbe, O. M. (2012). Influence of planting densities on the performance of intercropped bambara groundnut with cowpea in Makurdi, Benue state, Nigeria. International Journal of Development and Sustainability, 1(3).

Ali, S., \& Mohammad, H. S. (2012). Forage yield and quality in intercropping of forage corn with different cultivars of berseem clover in different levels of nitrogen fertilizer. Journal of Food, Agriculture and Environment, 10(1), 602-604.

Allen, J. R., \& Obura, R. K. (1983). Yield of corn, cowpea and soybean under different intercropping systems. Agronomy Journal, 75, 1005-1009. http://dx.doi.org/10.2134/agronj1983.00021962007500060032x

Amos, R. N., Jens, B. A., \& Symon, M. (2012). On farm evaluation of yield and economic benefits of short term maize legume intercropping systems under conservation Agriculture in Malawi. Field crop research, 132, 149-157.

Anders, M. M., Potdar, M. V., \& Francis, C. A. (1996). The significance of Intercropping in cropping systems. In O. Ito, C. Johansen, J. J. Adu-Gyamfi, K. Katayama, J. V. D. Kumar, K. Rao, \& T. J. Rego (Eds.), Dynamics of roots and nitrogen in cropping systems of the semi-arid tropics. Japan International Research Center for Agricultural Sciences. International Agricultural Series No. 3 Ohwashi, Tsukuba, Ibavaki 305, Japan. http://dx.doi.org/10.1016/j.agee.2007.05.008

Arvindkumar, Singh, S. N., \& Gajendra, G. (2004). Influence of planting ratio and Fertilizer application on dry matter production LAI and nutrient content and uptake by maize and groundnut in intercropping. Annals of Agricultural Research, 25(2), 283-288.

Askegaard, M., \& Eriksen, J. (2008). Residual effect and leaching of N and K in cropping systems with clover and ryegrass catch crops on a coarse sand. Agriculture, Ecosystems and Environment, 123(1-3), 99-108.

Bamshaiye, O. M., Adegbola, J. A., \& Bamshaiye, E. I. (2012). Bambara groundnut: An under- utilized nut in Africa. Advances in Agricultural Biotechnology, 1(2011), 60-72.

Beets, W. C. (1990). Raising and sustaining productivity of small holder systems in the tropics: A handbook of sustainable Agricultural development. Alkamaar, Netherlands: Agbe Publishing.

Bhagad, S. B., Chavan, S. A., Zagade, M. V., \& Dahiphale, A. V. (2006). Intercropping groundnut and sweet corn at different fertility levels and row proportions. Indian Journal of Crop Science, 1(1-2), 151-153.

Brintha, I., \& Seran, T. H. (2009). Effect of paired row planting of raddish (Raphanus SativusL.) intercropped with vegetable amaranths (Amaranths tricolor L.) on yield components in sandy regosol. J. Agric. Sci., 4, 19-28. 
Chalka, M. K., \& Nepalia, V. (2006). Nutrient uptake appraisal of maize intercropped with legumes and associated weeds under the influence of weed control. Indian Journal of Agricultural Research, 40, 86-91.

Chui, J. A. N., \& Richard, S. (1984). Influence of spatial arrangement of maize on performance of an associated soybeans intercrop. Field crop Res., 8, 187-198. http://dx.doi.org/10.1016/0378-4290(84)90062-5

Dado, R. G. (1999). Nutritional benefit of specialty Maize grain Hybrid in Dairy diets. Journal of Animal Science, 197-207.

Dahmardeh, M. (2013). Intercropping two varieties of Maize (Zea mays L) and Peanut (Arachishypogaea L): Biomass yield and intercropping advantage. Int. J. Agric. And Forestry, 3(1), 7-11.

Dahmardeh, M., Ghanbari, A., Syahsar, B. A., \& Ramrodi, M. (2010). The role of intercropping maize (Zea mays L) and cowpea (Vignaunguiculata L) on yield and soil chemical properties. Afr. J. Agric. Res., 5, 631-636.

Dalal, R. C. (1977). Effects of intercropping of maize with soybeans on grain yields. Tropical Agric. (Trinidad), $54,189-191$.

Dimitrios, B., Panyiota, P., Aristidis, K., \& Aspasia, E. (2010). Weed suppression effects of maize- vegetable in organic farming. Int. J. Pest Mang, 56, 173-181. http://dx.doi.org/10.1080/09670870903304471

Egbe, O. M., Alibo, S. E., \& Nwueze, I. (2010). Evaluation of some extra-early-and early- maturing cowpea varieties for intercropping with maize in southern guinea savanahof Nigeria. Agriculture and Biology Journal of North America. http://dx.doi.org/10.5251/abjna.2010.1.5.845.858

Emine, B. C., Celik, N., \& Bayram, G. (2010). Yield and quality of forage Maize as influence by plant density and nitrogen rates . Turkish Journal of Field Crops, 15(2), 128-132.

Fawusi, M. O. A., \& Wanki, S. B. C. (1982). Plant density effects on growth, yield, leaf area index and light transmission on intercropped maize (Zea mays L.) and cowpea (Vignaunguiculata L. Walp). Nigeria Journal of Agricultural Sciences, 99, 19-23.

Fininsa, C. (1997). Effect of planting pattern, relative planting data and intra-row spacing on aharicot bean/ maize intercrop. African Crop Science Journal, 5, 15-22. http://dx.doi.org/10.4314/acsj.v5i1.27866

Flores-Sanchez, D., KleineKoerkamp-Rabelista, J., Navarro-Garza, H., Lantinga E. A., Rossing, W. A. H., \& Kropff, M. J. (2011). Diagnosis of agro-ecological engineering of maize-based smallholder farming systems in Costa Chica, Guerrero state, Mexico. Nutrient Cycling in Agro- Ecosystems.

Flores-Sanchez, D., Pastor, A., Janssen, B. H., Lantinga, E. A., Rossing, W. A. H., \& Kropff, M. J. (2012). Comparison of organic and inorganic nutrient inputs for productivity enhancement in smallholder maizebased systems in South West Mexico. http://dx.doi.org/10.1007/s10705-011-9455-z

Flores-Sanchez, D., Pastor, A., Janssen, B. H., Lantinga, E. A., Rossing, W. A. H., \& Kropff, M. J. (2013). Exploring Maize-Legume intercropping systems in South West MexicoAgroecology and Sustainable Food Systems.

Foster, A., \& Malhi, S. S. (2013). Influence of Seeding date on growing seasons conditions on forage yield and quality of four annual crops in Northeastern Saskatchewan. Communication in Soil Science and Plants Analysis, 44, 884 -891. http://dx.doi.org/10.1080/00103624.2012.747610

Francis, C. A. (1986). Multiple cropping systems. Macmillan, Newyork.

Fukai, S. (1993). Intercropping- bases of productivity. Field crops Research, 34, 239-245. http://dx.doi.org/10.1016/0378-4290(93)90116-5

Fukai, S., \& Trenbath, B. R. (1993). Processes determining intercrop productivity and yield of component crops. Field crops Research, 34, 247 -271. http://dx.doi.org/10.1016/0378-4290(93)90117-6

Fusuo, Z., \& Li, L. (2003). Using competitive and facultative interaction in intercropping systems enhances crop productivity and nutrients use efficiency. Plant and soil, 248, 305-312. productivity and nutrients use efficiency. Plant and soil, 248, 305-312. http://dx.doi.org/10.1023/A:1022352229863

Gabatshele. M. L., Marokane, T. K., \& Mojeremane, W. (2012). Effects of intercropping on the performance of maize and cowpeas in Botswana. Journal of Agriculture and Forestry, 2(6), 307-310. http://dx.doi.org/10.5923/j.ijaf.20120206.07

Gangwar, K. S., \& Sharma, S. K. (1994). Fodder legume intercropping in maize (Zea mays) and its effect on succeeding wheat (Triticumaestivum). Indian Journal of Agricultural Sciences, 64(1), 38-40. 
Gardner, F. P., \& Kisakye, J. (1990). Productivity of bean/maize intercrops as influenced by bean type and planting date and maize density. Proceedings Soil and Crop Science Society of Florida, 49, 139-146.

Geiler, K. E. (2001). Nitrogen fixation in tropical cropping system (2nd ed.). CABI publishing, Wallingford, UK. http://dx.doi.org/10.1079/9780851994178.0000

Geiler, K. E., Ormesher, J., \& Awa, F. M. (1991). Nitrogen transfer from Phaseolus bean to intercropping maize measured using 15-N enrichment and 15-N isotope dilution methods. Soil Biol. Biochem, 23, 239-246.

Ghanbari-Bonjar, A. (2000). Intercropping field bean (Viciafaba) and wheat (Triticum aestivumL.) as a low-input forage. $\mathrm{PhD}$ thesis. Wye College, University of London, UK.

Goli, A. E. (1997). Conservation and improvement of bambaragroundnut (Vigna subterranean (L.) Verdc.). In Helle et al. (Eds), Bibliographical Review, Proceedings of an International Workshop held at Harare, Zimbabwe (pp. 4-10).

Gurigbal, S. (2010). The soybean: Botany, Production and Uses. Ludhiana, India: Cabi Publishers. http://dx.doi.org/10.1079/9781845936440.0000

Halikatti, S. I., \& Banarasilal, B. (2011). Production Potentiality of Maize as Influenced by Planting Geometry, Mulching and Grain Legume Intercropping. Karnataka Journal of Agricultural Sciences, 11(4).

Hamdollah, E. (2012). Yield and Quality of forage produced in intercropping of maize (Zea mays L.) with cowpea (Vignasinensis L.) and Mungbean (Vigna radiate L.) as double cropped. J. Basic Appli. Sci. Res., 2(1), 93-97.

Hamidou, F., Halilou, O., \& Vadez, V. (2013). Assessment of Groundnut under combined heat and Drought stress. J. Agronomy and Crop science, 199, 1-11. http://dx.doi.org/10.1111/j.1439-037X.2012.00518.x

Hiebsch, C. K., \& Macollam, R. E. (1980). Area time equivalency ratio. A method for evaluating the productivity of intercrops. Agronomy Journal, 75, 15-22.

Hillocks, R. J., Bennett, C., \& Mponda, O. M. (2012). Bambara nut: A Review of utilisation, market potential and crop improvement,African Crop Science Journal, 20(1), 1-16.

Hongchun, X., Shen, H., Zhang, L., Zhang, Y., Guo, X., Wang, P., ... Zuo, Y. (2013). Comparative proteomic analysis for assessement of the ecological significance of maize and peanut intercropping. Journal of Proteomics, 78, 447-460. http://dx.doi.org/10.1016/j.jprot.2012.10.013

Hugar, H. Y., \& Palled, Y. B. (2008). Studies on maize-vegetable intercropping systems. Karnataka J. Agric. Sci., $21,162-164$.

ICRISAT. (2009). International Crops Research Institute for the Semi-Arid Tropics (ICRISAT) Groundnut. Retrieved 17 May 2013, from http://www.icrisat.org/groundnut/GroundNut.htm

Ijoyah, M. O. (2012). Review of intercropping research on cereal- vegetable based cropping system, Scientific Journal of crop Science, 1(3), 55-62.

Ijoyah, M. O., \& Fanen, F. T. (2012). Effects of different cropping pattern on performance of maize-soybean mixture in Makurdi, Nigeria. J. Crop Sci., 1(2), 39-47.

Ijoyah, M. O., \& Jimba, J. (2012). Evaluation of yield and yield components of maize (Zea mays L.)and okra (Abelmoschus esculentus) intercropping system at Makurdi, Nigeria. J. Bio. Env. Sci., 2(2), 38-44.

Innis, W. H. (1997). Intercropping and the scientific basis of traditional Agriculture (1st ed.). London: Intermediate Technology Publications Ltd.

Jakusko, B. B., \& Belel, M. D. (2009). The effects of different level of phosphorous on quantitative characters/yield and productivity of bambaran groundnuts(Vigna subterranean) in Yola. Techno Science African Journal, 311, 13-15.

Jane, G. A., Godfrey, W. N., Gideon, N. M., \& David, M. M. (2012). NaCl salinity affects germination,growth,physiology and biochemistry of Bambara groundnut. Brazilian Journal of Plant Physiology, 24(3), 151-160. http://dx.doi.org/10.1590/S1677-04202012000300002

Jensen, E. S. (1996). Grain yield, symbiotic N2 fixation and interspecific competition for inorganic N in pea-barley intercrops. Plant Soil, 182, 25-38. http://dx.doi.org/10.1007/BF00010992 
Jeyakumaran, J., \& Seran, T. H. (2007). Studies on intercropping capsicum (Capsicum annum L.) withBushitao (Vigna unguiculata L.) Proceedings of the 6th Annual Research Session (pp. 431-440), Oct. 18-19, Trinconalee campus, EUSL.

Jiao, N. Y., Zhao, C., Ning, T. Y., Hou, L. T., Fu, G. Z., Li, Z. J., \& Chen, M. C. (2008). Effect of maize peanut intercropping on economic yield and light response of photosynthesis. Chinese J. Applied Ecol., 19, 981- 985

Jorge, A. C., \& Joseph, G. L. (1999). Plant density and hybrid Influence in corn forage yield and quality. Agron. J, 91, 911 -915. http://dx.doi.org/10.2134/agronj1999.916911x

Kanakeri, V. V. (1991). Studies on intercropping of legumes in kharifmaize and their Residual effect on succeeding wheat. M.Sc.(Agri.) Thesis, University of Agricultural Sciences, Dharwad.

Karikari, S. K. (2003). A decade of Bambara groundnut agronomic research at the Botswana College of Agriculture. UNISWA J. of Agric., 12, 24-28.

Keating, B. A., \& Carberry, P. S. (1993). Resource capture and use in intercropping: solar radiation. Field Crop Res., 34, 273-301. http://dx.doi.org/10.1016/0378-4290(93)90118-7

Khan, Z., Saeed, A., Zada, K., \& Ahmad, S., (1992). Biologic and intercrop studies on yield and nitrogen fixation of soybean and maize. Sarhad Journal of Agriculture, 8, 613-622.

Koli, E. S. (1975). Pure cropping and mixed cropping of maize and groundnuts. Neth. J. Agric. Sci., 26, 344-353.

Li, L., Sun, J., Zhang, F., Li, X., Yang, S., \& Rengel, Z. (2001). Wheat/maize or wheat/soybean strip intercropping I yield advantage and interspecific interaction on nutrients. Field Crop Res., 71, 123-137. http://dx.doi.org/10.1016/S0378-4290(01)00156-3

Lithourgidis, A. S., Vasilakoglou, I. B.,Dhima, K. V., Dordas, C. A., \& Yiakoulaki, M. D. (2006). Forage yield and quality of common vetch mixtures with oat and triticale in two seeding ratios. Field.Crops. Res., 99, 106- 113. http://dx.doi.org/10.1016/j.fcr.2006.03.008

Maluleke, M. H., Bediako, A. A., \& Ayisi, K. K. (2005). Influence of maize-lablab intercropping on Lepidopterous stem borer infestation in maize. J. Entom., 98, 384-388. http://dx.doi.org/10.1603/0022-0493-98.2.384

Mandal, B. K., Dhara, M. C., Mandal, B. B., Das, S. K., \& Nandy, R. (1990). Rice, Mungbeans, Soybeans, Peanut, Ricebean, and Blackgram yields under different intercrop systems. Agrons. J., 82, 1063-1066. http://dx.doi.org/10.2134/agronj1990.00021962008200060006x

Mangasini, A. K., Mwanahawa, L. M., Arbogast, G. M., \& Neema, P. K. (2012). Agronomic factors limiting groundnut production: A case of smallholder farming in Taboraregion. 17th Annual Research Workshop Dar es Salaam, Tanzania; March 28-29, 2012

Matusso, J. M. M., Mugwe, J. N., \& Mucheru-Muna, M. (2012). Potential role of cereal-legume intercropping systems in integrated soil fertility management in smallholder farming systems of sub-Saharan Africa Research Application Summary. Third RUFORUM Biennial Meeting 24-28 September 2012, Entebbe, Uganda

Metwally, A. E. A., Shafik, M. M., \& Tamer, A. W. (2012). Effect of intercropping corn on Egyptian cotton characters. The J. cotton Sci., 16, 210-219.

Meyer, R. (2010). Low-input intensification in agriculture chances for small-scale farmers in developing countries. GAIA-Ecol. Perspect. Sci. Soc., 19, 263-268.

Mohan, H. M. (2003). Maize based intercropping studies with grain legumes in vertisols. M.Sc. (Agri.) Thesis, University of Agricultural Sciences, Dharwad.

Morris, R. A., \& Garrity, D. P. (1993). Resource capture and utilization in intercropping: water. Field Crop Res., 34, 303-317. http://dx.doi.org/10.1016/0378-4290(93)90119-8

Mucheru-Muna, M., Pypers, P., Mugendi, D., Kungu J., Mugwe, J., Merckx, R., \& Vanlauwe, B. (2010). Staggered maize-legume intercrop arrangement robustly increases crop yields and economic returns in the highlands of Central Kenya. Field Crops Research, 115, 132-139. http://dx.doi.org/10.1016/j.fcr.2009.10.013

Musa, M., Singh, A., Abubakar, L., Noma, S. S., Alhassan, J., \& Haliru, B. S. (2012). Influence of cultivar and sokoto phosphate rock levels on the yield and yield components of groundnuts (Arachis hypogea L) in dry sub-humid sokoto area, Nigeria. Nigerian Journal of Basic and Applied Sci., 20(1), 49-54. 
Nweke, I. A., \& Emeh, H. O. (2013). The response of Bambara ground nut (Vigna subterranean (L) verdc) to phosphate fertilizers levels in IgbarianSouthEast Nigeria. IOSR J. of Agric \& Vet. Sci., 2(1), 28-34. http://dx.doi.org/10.9790/2380-0212834

Ofori, F., \& Stern, W. R. (1987). Cereal-legume intercropping systems. Adv. Agron., 41, 41-90. http://dx.doi.org/10.1016/S0065-2113(08)60802-0

Ogah, E. O., \& Ogbodo, E. N. (2012). Assessing the impact of biodiversity conservation in the management of Maize Stalk Borer (Busseolafusca F.) in Nigeria. Current Trends in Technology and Science Vol. II Issue IIPg $234-238$.

Osman, A. N., Ræbild, A., Christiansen, J. L., \& Bayala, J. (2011). Performance of cowpea (Vignaunguiculata) and Pearl Millet (Pennisetumglaucum) Intercropped under Parkiabiglobosain an Agroforestry System in Burkina Faso. African Journal of Agricultural Research, 6(4), 882-891.

Oyewole, C. I. (2010). Maize (Zea mays L.)-Okra (Abelmoschus esculentus(L) Moench) intercropping as affected by cropping pattern in kogi state, Nigeria. ContinentalJ. Agronomy, 4, 1-9.

Pandita, A. K., Shah, M. H., \& Bali, A. S. (2000). Effect of row ratio in cereal-legume intercropping systems on productivity and competition functions under Kashmir conditions. Indian Journal of Agronomy, 45, 48-53.

Portes, T. D. A. (1984). Profile of light interception and yields of six bean (Phaseolus vulgaris L.) cultivars of different growth habits intercropped with maize (Zea mays L.), Field Crop Abst., 37(6), 491.

Prasad, R. B., \& Brooks, R. M. (2005). Effects of varying maize density on intercropped maize and soybeans in Nepal.Exp.Agric., 41, 365-382. http://dx.doi.org/10.1017/S0014479705002693

Putnam, D. H., Herbert, S. J., \& Vargas, A. (1986). Intercropped corn-soybean density studies, II.Yield composition and protein. Exp. Agric., 22, 373-381. http://dx.doi.org/10.1017/S0014479700014629

Rana, K. S., \& Pal, M. (1999). Effect of intercropping systems and weed control on crop-weed competition and grain yield of pigeonpea. Crop Res., 17, 179-182.

Rao, M. R., \& Willey, R. W. (1980). Evaluation of yield stability in intercropping studies On sorghum/pigeonpea. Experimental Agriculture, 16, 105-106. http://dx.doi.org/10.1017/S0014479700010796

Raposo, J. A. D. E. A., Schuch, L., Assis, F. N. D. E., Machado, A. A., \& De-Assis, F. N. (1995). Intercropping of maize and beans in different plant arrangements anddensities in pelotas, pesquisa. Agropecuaria Brasilleira, 30, 639-647.

Reddy, T. Y., \& Reddi, G. H. S. (2007). Principles of Agronomy (pp. 468-489). Kalyan Publishers India.

Remison S. U. (1978). Neighbour effects between maize and cowpea at various levels of N and P. Expl. Agric., 14, 205-212. http://dx.doi.org/10.1017/S001447970000870X

Ross, S. M., King, J. R., Donovan, J. T., \& Spaner, D. (2005). The productivity of oats and berseem clover intercrops. I. Primary growth characteristics and forage quality at fourdensities of oats. grass. Forage. Sci., 60, 74-86. http://dx.doi.org/10.1111/j.1365-2494.2005.00455.x

Rusinamhodzi, L., Corbeels, M., Justice, N., \& Ken, E. G. (2012). Maize- Grain legume intercropping is an attractive option for ecological intensification that reduces climatic risk for smallholder farmers in central Mozambique. Field Crop Res., 136, 12-22. http://dx.doi.org/10.1016/j.fcr.2012.07.014

Sanginga, N., \& Woomer, P. L. (2009). Integrated soil fertility management in Africa: Principles, Practices and Development Process. (Eds.). Tropical Soil Biology and Fertility. Institute of the International Centre for Tropical Agriculture. Nairobi.

Seran, T. H., \& Brintha, I. (2010). Review on maize based intercropping. Journal of Agronomy, 9(3), 135-145. http://dx.doi.org/10.3923/ja.2010.135.145

Shafik, M. M., \& Soliman, A. M. (1999). Effect of intercropping grain sorghum and soybean on yield and yield components. Proc. $1^{\text {st }}$ conf. Recent Technologiesin Agric. Cairo Univ. 27-29, Nov. Vol. 11, 277-283

Shi, Y., Ma, Y., Ma, W., Liang, C., Zhao, X., Fang, J., \& He, J. (2013). Large scale patterns of forage yield and quality across Chinese grasslands. Chinese Science Bulletin, 58(10), 1187-1199. http://dx.doi.org/10.1007/s11434-012-5493-4

Singh, N. B., Singh, P. P., \& Nair, K. P. P. (1986). Effect of legume intercropping on Enrichment of soil nitrogen, bacterial activity and productivity of associated maize crops. Exp. Agric., 22, 339-344. http://dx.doi.org/10.1017/S0014479700014587 
Smith, S. (2002). Growing corn with companion crop legumes for high protein silage, Green book Energy and Sustainable Agriculture Program (pp. 68-70). Minnesota Dep. Agric. USA.

Sorrensen, R., Butts, C., Lamb, M., \& Rowland, D. (2004). Five years of subsurface drip irrigation on Peanut. UGA/CPES Research and Extension Bulletin No.2004.

Steiner, K. G. (1991). Overcoming soil fertility constraints to crop production in West Africa: Impact of traditional and improved cropping systems on soil fertilizer. In A. U. Mokwunye (Ed.), Alleviating Soil Fertility constraints to increased crop production in West Africa (pp. 69-91). http://dx.doi.org/10.1007/978-94-011-3224-4_7

Stern, W. R. (1993). Nitrogen fixation and transfer in intercrop systems. Field Crops Res., 34, 335-356. http://dx.doi.org/10.1016/0378-4290(93)90121-3

Sullivan, P. (2003). Intercropping principles and production practices. Appropriate Technology Transfer for Rural Areas Publication. Retrieved from http://www.attra.ncat.org

Taru, V. B., Kyagya, I. Z., Mshelia, S. I., \& Adebayo, E. F. (2008). Economic efficiency of resource use in Groundnut production in Adamawa State of Nigeria. World Journal of Agricultural Sciences, 4(S), 896-900.

Thayamini, H. S., \& Brintha, I. (2010). Review on Maize based intercropping. Journal of Agronomy, 9(3), 135-145. http://dx.doi.org/10.3923/ja.2010.135.145

Thole, A. (2007). Adaptability of soybeans [Glycine max(L)merr] varieties to intercropping under leaf stripped and detasselled Maize (Zea mays L.). M. Sc thesis, Department of crop science, University of Zimbabwe.

Trenbath, B. R. (1986). Resource use by intercrops. In C. A. Francis (Ed.), Multiple cropping systems (pp. 57-86). New York: Macmillan publishing co.

Troy, S. (2011). Graze Standing Corn for Forage Flexibility. Angus Journal, 3(6), 118.

Undie, U. L., Uwah, D. F., \& Attoe, E. E. (2012). Effect of intercropping and crop arrangement on yield and productivity of late season Maize/soybean mixtures in the humid environment of South Southern Nigeria. Journal of Agricultural Science, 4(4), 37-50. http:dx.doi.org/10.5539/jas.v4n4p37

Vandermeer, J. (1989). The ecology of intercropping. New York: Cambridge University press. http://dx.doi.org/10.1017/CBO9780511623523

Vara Prasad, P. V., Craufurd, P. Q., \& Summerfield, R. J. (1999). Fruit number in relation to pollen production andviability in groundnut exposed to short episodes of heat stress. Annals of Bot., 84, 381-386. http://dx.doi.org/10.1006/anbo.1999.0926

Vesterager, J. M., Nielsen, N. E., \& Hogh-Jensen, H. (2008). Effects of cropping history and phosphorus source on yield and nitrogen fixation in sole and intercropped cowpea- maize systems. Nutrients Cycling Agrosystems, 80, 61-73. http://dx.doi.org/10.1007/s10705-007-9121-7

Waddington, S. R., \& Edward, A. F. (1989). Research methods for cereal- legume intercropping. Proceedings of the Workshop on research Methods for cereals /legumes intercropping in Eastern and Southern Africa (pp. 69-69). Jan. 23-27, Malawi. http://dx.doi.org/10.1017/S0014479707005303

Waddington, S. R., Mekuria, M., Siziba, S., \& Karigwindi, J. (2007). Long-term yield sustainability and financial returns from grain legume-maize intercrops on a sandy soil in subhumidNorth Central Zimbabwe. Experimental Agriculture, 43, 489-503.

Wahid, A., Gelani, S., Ashraf, M., \& Foolad, M. R. (2007). Heat tolerance in plants: An overview. Env. Exp. Bot., 61, 199-223. http://dx.doi.org/10.1016/j.envexpbot.2007.05.011

Wamba, O. F., Taffouo, V. D., Youmbi, E., Ngwene, B., \& Amougou, A. (2012). Effects of organic nutrient sources on the growth, total chlorophyll and yield of three Bambara groundnut landraces in the coastal region of Cameroon. J. Agron., 11(2), 31-42. http://dx.doi.org/10.3923/ja.2012.31.42

Widdicombe, D., \& Thelen, K. D. (2002). Row width and plant density effect on corn forage hybrids. Agron. J., 94, 326 -330. http://dx.doi.org/10.2134/agronj2002.0326

Willey, R. W. (1979). Intercropping its importance and research needs, Part-I, Competitionand yield advantages. Field Crop Abstracts, 32, 1-10.

Yilmaz, S., Gozubenli, H., Kruskan, O., \& Atis, I. (2007). Genotype and plant density effect on corn (Zea mays L.) forage yield. Asian J. Plant Sci, 6(3), 538-541. http://dx.doi.org/10.3923/ajps.2007.538.541 
Zam-Ali, S. N., Matthews, R. B., Williams, J. H., \& Peacock, J. M. (1990). Light use, water uptake and performance of individual components of sorghum groundnut intercrop. Exp. Agric., 26,413-427. http://dx.doi.org/10.1017/S0014479700001344

ZHANG, J. W., Chang-hao, H. U., Kong-jun, W. A. N. G., Shu-ting, D. O. N. G., \& Peng, L. I. U. (2004). Effects of plant density on forage nutritive value of whole plant corn. Agricultural Sci. in China, 3(11), 842-848.

Zuo, Y. M., Zhang, F. S., Li, X. L., \& Cao, Y. P. (2000). Studies on the improvement in iron nutrition of peanut by intercropping with maize on a calcareous soil. Plant Soil, 220, 13-25. http://dx.doi.org/10.1023/A:1004724219988

\section{Copyrights}

Copyright for this article is retained by the author(s), with first publication rights granted to the journal.

This is an open-access article distributed under the terms and conditions of the Creative Commons Attribution license (http://creativecommons.org/licenses/by/3.0/). 